\title{
Pengaruh Variabel Ekonomi Makro Pada Nilai Intrinsik Saham
}

\author{
I Komang Gede Darma Putra Sadia ${ }^{1}$ \\ I Gde Ary Wirajaya ${ }^{2}$
}

\author{
${ }^{1,2}$ Fakultas Ekonomi dan Bisnis Universitas Udayana (Unud), Bali, Indonesia \\ e-mail : darmaputrasadia.dp@gmail.com
}

\begin{abstract}
ABSTRAK
Tujuan penelitian ini adalah untuk mengetahui dan mendapatkan bukti empiris pengaruh nilai tukar rupiah dan produk domestik bruto pada nilai intrinsik saham. Populasi penelitian ini adalah perusahaan non keuangan yang terdaftar di Bursa Efek Indonesia periode 20162017. Sumber data yang digunakan dalam penelitian ini adalah data sekunder yang diperoleh pada laporan tahunan perusahaan yang terdaftar di Bursa Efek Indonesia dengan mengakses situs www.idx.co.id dan website perusahaan. Teknik sampling yang digunakan adalah purposive sampling dengan jumlah sampel 283 perusahaan dalam 2 tahun, sehingga secara total diperoleh 566 total amatan. Analisis data yang digunakan dalam penelitian ini adalah analisis regresi linier berganda. Berdasarkan hasil analisis ditemukan bahwa variabel nilai tukar rupiah berpengaruh negatif pada nilai intrinsik saham. Sedangkan variabel produk domestik bruto memiliki pengaruh positif pada nilai intrinsik saham.
\end{abstract}

Kata Kunci: Price Earning Ratio, Nilai Tukar Rupiah, Produk Domestik Bruto

\begin{abstract}
The purpose of this study was to find out and obtain empirical evidence of the effect of the rupiah exchange rate and gross domestic product on the intrinsic value of shares. The population of this study is non-financial companies listed on the Indonesia Stock Exchange for the period 2016-2017. The data sources used in this study are secondary data obtained in the annual reports of companies listed on the Indonesia Stock Exchange by accessing the site www.idx.co.id and the company's website. The sampling technique used was purposive sampling with a total sample of 283 companies in 2 years, so that in total 566 total observations were obtained. The data analysis used in this study is multiple linear regression analysis. Based on the results of the analysis it was found that the rupiah exchange rate variable had a negative effect on the intrinsic value of shares. While the gross domestic product variable has a positive influence on the intrinsic value of shares.

Keywords: Price Earning Ratio, Rupiah Exchange Rate, Gross Domestic Product
\end{abstract}

\section{PENDAHULUAN}

Investor dalam berinvestasi sangat penting untuk mengetahui nilai wajar saham, hal ini akan mempermudah investor dalam memperkirakan kemungkinan keuntungan serta kerugian yang akan terjadi di masa depan. Menurut Jogiyanto (2003) terdapat tiga nilai yang dimiliki oleh saham, yang pertama adalah nilai buku, yang kedua adalah nilai pasar, dan yang terakhir 
adalah nilai intrinsik. Untuk melihat aset bersih dari kepemilikan satu lembar saham dilihat dari nilai buku per lembar saham. Untuk melihat harga saham yang ada di pasar saham dapat dilihat dari nilai pasarnya. Nilai intrinsik yaitu nilai yang menentukan harga wajar dari suatu saham sehingga saham tersebut menjelelaskan nilai saham sesungguhnya jadi harganya tidak terlalu tinggi (Sulistyastuti, 2002).

Fenomena overreaction terjadi di pasar modal dimana dalam www.economy.okezone.com mengatakan melemahnya nilai tukar rupiah beberapa hari terakhir juga berimbas pada pasar modal Indonesia. IHSG pada perdagangan Rabu 5 September 2018 bahkan tercatat turun 3,7\% ke 5.683,50. Kepala Eksekutif Pengawas Pasar Modal OJK mengatakan, pelemahan IHSG disebabkan adanya spekulasi dari para pelaku pasar. Di mana kondisi pelemahan Rupiah membuat pelaku pasar panik dan menjual portofolionya. Hal ini yang membuat BEI bersama OJK, juga Bank Indonesia menggelar diskusi untuk menjelaskan kondisi perekonomian nasional kepada para pelaku pasar. Oleh sebab itu, dirinya menekankan untuk para pelaku pasar tak terpengaruh dengan spekulator. Dirinya bahkan mengajak para pelaku pasar mengambil kesempatan membeli ketika pasar sedang jatuh, sebab banyak saham murah yang sudah undervalue. Oleh karena itu, para investor terlebih dahulu perlu melakukan penilaian-penilaian terhadap saham sebelum membuat keputusan membeli, menahan, atau menjual saham tersebut (Wulandari, 2010).

Nilai perusahaan dan kinerja perusahaan dapat dipengaruhi oleh faktor eksternal yang salah satunya adalah kondisi dari ekonomi makro. Fama (1981) 
menyatakan untuk melakukan prediksi perubahan harga saham dapat dilihat dari perubahan atau pergerakan dari ekonomi makro (Wulandari, 2010). Menurut Charitou, A.Gimeno-Gascon, F. Woo. C. (2004) ekonomi makro seperti suku bunga yang tinggi dapat mengakibatkan kesulitan bagi perusahaan dan kemudian menurunkan kinerja perusahaan tersebut. Berbeda dengan Charitou, Wulandari (2010) memilih laju inflasi yang tinggi yang menjelaskan variabel ekonomi makro. Laju inflasi yang tinggi dianggap dapat menyulitkan keuangan perusahaan dan kemudian berdampak pada kinerja perusahaan tersebut. Selain suku bunga dan laju inflasi, Rachmawati (2012) menyebutkan adanya fluktuasi dari nilai tukar dapat menyebabakan terjadinya kesulitan keuangan bagi perusahaan dan akann berdampak pada kinerja keuangannya. Oleh karena itu penelitian ini berfokus kepada faktor eksternal yaitu ekonomi makro.

Faktor ekonomi makro yang dapat memengaruhi nilai intrinsik sahammerupakan sebuah keadaan atau kejadian yang bersifat global atau menyeluruh mengenai ekonomi Indonesia yang dapat mempengaruhi harga saham. Faktor ekonomi makro terjadi di luar perusahaan sehingga sulit bagi perusahaan untuk mengendalikannya, seperti masalah nilai tukar rupiah terhadap mata uang asing (Nopirin, 2009) dan Produk Domestik Bruto (PDB). Investor akan mengamati keadaan-keadaan yang mungkin dapat memengaruhi harga saham yang dimilikinya.

Nilai tukar uang yaitu perbandingan nilai atau harga antara dua mata uang yang dipertukarkan. Perbandingan nilai ini disebut dengan kurs atau exchange 
rate (Nopirin., 2009). Jika terjadi peningkatan terhadap permintaan sebuah mata uang, sedangkan penawaran mata uang tersebut tetap atau justru menurun, maka nilai mata uang tersebut akan naik. Sedangkan jika permintaan terhadap mata uang menurun, namun terjadi peningkatan pada penawaran matauang, maka yang terjadi adalah nilai tukar uang tersebut akan akan melemah. Terjadinya perubahan terhadap nilai tukar mata uang dapat mempengaruhi sebuah perusahaan, terutama bagi perusahaan yang melakukan impor dan perusahaan yang berorientasi ekspor. Nilai mata uang yang terdepresiasi memberikan keuntungan bagi perusahaan yang berproduksi di dalam negeri dan kemudian menjual produknya di luar negeri (ekspor) karena pendapatan yang diperoleh dalam mata uang asing akan meningkat nilainya saat ditukarkan dengan mata uang rupiah, sehingga keuntungan yang didapat lebih besar. Sedangkan bagi perusahaan berproduksi dengan menggunakan bahan baku impor, yang perlu mengeluarkan biaya lebih untuk memperoleh bahan bakunya saat rupiah terdepresiasi, nilai mata uang yang terdepresiasi menyebabkan keuntungan yang diperoleh akan menurun. Tinggi rendahnya laba yang dapat dihasilkan oleh perusahaan akan dapat mempengaruhi nilai intrinsik saham yang mungkin diperoleh oleh investor.

Arbitrage Pricing Theory (APT) yaitu ketika dua kesempatan investasi memiliki karakteristik-karakteristik yang serupa harus dijual dengan harga yang sama. Hukum satu harga atau the law of the one price adalah konsep yang dipakai dalam teori ini. Arbitrage akan muncul ketika melakukan pembelian aset dengan harga yang murah dan kemudian menjual kembali aset tersebut dengan harga yang lebih mahal yang kemudian mendapatkan laba tanpa adanya risiko, hal inilah yang 
terjadi ketika aset dengan karakteristik-karakteristik yang sama kemudian dijual dengan harga yang berbeda (Firdaus, 2016).

Terdapat banyak pertanyaan mengenai nilai dari suatu saham, bebrapa di antaranya adalah mengenai harga saham dan cerminannya terhadap perusahaan, jika tidak mencerminkan perusahaan tersebut maka berapa nilai yang sesungguhnya dari saham tersebut. Nilai intrinsik yaitu nilai yang menentukan harga wajar dari suatu saham sehingga saham tersebut menjelelaskan nilai saham sesungguhnya jadi harganya tidak terlalu tinggi (Sulistyastuti, 2002). Nilai intrinsik dapat dianalisi yaitu dengan dua analisis. Analisis yang pertama adalah analisis teknikal dan analisi yang ledua adalah analisis fundamental. Melakukan analisis untuk mendapatkan nilai intrinsik dengan menggunakan analisi fundamental yaitu menganalisis dengan memanfaatkan data-data keuangan perusahaan tersebut sedangkan melakukan analisis untuk mendapatkan nilai intrinsic dengan menggunakan analisis teknikal adalah dengan menggunakan data yang terdapat di pasar saham (Jogiyanto, 2003). Analisis fundamental menggunakan dua pendekatan untuk menghitung nilai intrinsik saham, yaitu dengan pendekatan PER (price earnings ratio) dan pendekatan nilai sekarang (present value).

Menurut Mankiw (2007) kurs atau exchange rate merupakan kesepakatan dari dua negara mengenai harga yang ditentukan untuk melakukan perdagangan. Terdapat dua jenis kurs, kurs yang pertama adalah kurs riil yaitu ketika kita bisa memperdagangkan barang dari suatu negara untuk barang dari negara lain. Kurs 
yang kedua adalah kurs nominal yaitu harga relatif dari mata uang dua negara (Dornbusch, 2008).

Produk domestik bruto atau PDB menjelaskan mengenai pendapatan serta pengeluaran total negara mengenaai output dari barang dan output dari jasa. Aktivitas ekonomi diringkas dalam suatu nilai uang. Meringkas aktivitas ekonomi pada periode tertentu tersebut merupakan tujuan dari PDB (Mankiw G, 2007). Terjadi perubahan PDB nominal tiap tahunnya. Perubahan ini didasari oleh alasan bahwa output fisik dari barang yang terus fluktuasi serta harga pasar yang terus fluktuasi tiap tahunnya. Lebih baik menggunakan PDB riil dari pada PDB nominal dalam penggunaan sebagai ukuran dasar dalam membandingkan ouput pada tahun yang berbeda (Dornbusch, 2008). PDB mencakup semua hal yang diproduksi oleh perekonomian dan yang dijual secara legal di pasar.

Nilai tukar mata uang adalah perbandingan nilai atau harga antara dua mata uang yang dipertukarkan. Perbandingan nilai ini disebut dengan kurs atau exchange rate (Nopirin., 2009). Arbitrage Pricing Theory menyatakan bahwa return untuk suatu sekuritas akan dipengaruhi oleh faktor ekonomi dan bukan karakteristik khusus perusahaan, dimana saat melemahnya nilai tukar rupiah maka akan menurunkan nilai pasar sehingga terdapat kesempatan untuk melakukan arbitage dengan membeli saham yang berharga murah dan pada saat yang sama menjualnya dengan harga yang lebih tinggi sehingga memperoleh laba tanpa risiko. 
Penelitian Mirayanti (2017) menyatakan bahwa nilai tukar rupiah berpengaruh negatif signifikan terhadap return saham. Jadi semakin melemahnya nilai tukar rupiah membuat daya tarik pasar modal berkurang karena investor lebih berhati-hati dalam melakukan investasi.

Pergerakan nilai tukar rupiah terhadap mata uang asing (seperti rupiah terhadap dollar) dapat mempengaruhi investasi di dalam negeri. Menurunnya nilai rupiah dapat membuat daya tarik pasar modal berkurang karena investor lebih berhati-hati dalam melakukan investasi dalam pasar modal terutama pada perusahaan yang menggunakan bahan baku impor. Dengan melemahnya rupiah terhadap mata uang asing, investor akan memiliki alternatif lain dalam berinvestasi yaitu dengan berinvestasi pada valuta asing. Hal tersebut akan menyebabkan menurunnya permintaan akan saham sehingga harga saham akan mulai menurun.

$\mathrm{H}_{1}$ : Nilai tukar rupiah berpengaruh negatif terhadap nilai intrinsik saham.

Produk domestik bruto atau PDB menjelaskan mengenai pendapatan serta pengeluaran total negara mengenaai output dari barang dan output dari jasa. Aktivitas ekonomi diringkas dalam suatu nilai uang. Meringkas aktivitas ekonomi pada periode tertentu tersebut merupakan tujuan dari PDB (Mankiw G, 2007). Terjadi perubahan PDB nominal tiap tahunnya. Perubahan ini didasari oleh alasan bahwa output fisik dari barang yang terus fluktuasi serta harga pasar yang terus fluktuasi tiap tahunnya (Arif, 2014). Arbitrage Pricing Theory (APT) yaitu ketika dua kesempatan investasi memiliki karakteristik-karakteristik yang serupa harus dijual dengan harga yang sama. Hukum satu harga atau the law of the one price 
adalah konsep yang dipakai dalam teori ini. Arbitrage akan muncul ketika melakukan pembelian aset dengan harga yang murah dan kemudian menjualnya dengan harga yang tinggi yang kemudian mendapatkan laba tanpa adanya risiko, hal inilah yang terjadi ketika aset dengan karakteristik-karakteristik yang sama kemudian dijual dengan harga yang berbeda (Firdaus, 2016).

Penelitian Koostanto (2013)menyatakan bahwa produk domestik bruto berpengaruh positif signifikan terhadap return saham. PDB meningkat berarti daya beli masyarakat meningkat. Hal ini akan meningkatkan harga saham laba yang diperoleh perusahaan sehingga dapat meningkatkan harga saham perusahaan.

Salah satu indikator meningkatnya pertumbuhan ekonomi adalah adanya peningkatan PDB yang merupakan suatu kenaikan output perkapita jangka panjang (Thobarry, 2009). PDB meningkat berarti daya beli masyarakat meningkat. Dengan meningkatnya daya beli masyarakat maka masyarakat dapat menyerap produk-produk yang diproduksi oleh perusahaan lebih banyak dari sebelumnya. Hal ini akan meningkatkan laba yang diperoleh perusahaan sehingga dapat meningkatkan harga saham perusahaan tersebut.

$\mathrm{H}_{2}$ : Produk Domestik Bruto berpengaruh positif terhadap nilai intrinsik saham.

\section{METODE PENELITIAN}

Lokasi penelitian ini adalah perusahaan non keuangan yang terdaftar di Bursa Efek Indonesia (BEI) periode tahun 2016-2017 yang diakses resmi di situs Bursa Efek Indonesia (www.idx.co.id) dan Indonesian Capital Market Directory 
(ICMD) serta data nilai tukar rupiah dan produk domestik bruto dari tahun 20162017 dari website Bank Indonesia (www.bi.go.id) dan website Badan Pusat Statistik (www.bps.go.id).

Objek penelitian pada penelitian ini adalah nilai intrinsik saham pada perusahaan non keuangan yang terdaftar di Bursa Efek Indonesia (BEI) periode tahun 2016-2017.

Variabel adalah suatu atribut yang padanya dapat dilekatkan bilangan atau nilai. Variabel-variabel yang akan dianalisis dalam penelitian ini adalah variabel bebas atau independent variableyang diidentifikasi dalam penelitian ini adalah Nilai tukar rupiah dan Produk domestik bruto yang di analisis dengan regresi linear berganda (multiple regression) dengan menggunakan bantuan program komputer SPSS (Statistical Product Service Solution).

variabel terikat atau dependent variableyang diidentifikasi dalam penelitian ini adalah nilai intrinsik saham penelitian ini diukur dengan PER.

Menurut Jones (2004) adalah satu dari banyak faktor finansial yang dianggap menarik bagi analis saham serta manajer keuangan. Literatur sebelumnya telah meneliti bagaimana rasio $\mathrm{P} / \mathrm{E}$ dapat digunakan untuk memperkirakan biaya modal ekuitas (Easton, 2004), untuk menjelaskan harga saham (Liu, Nissim, \& Thomas, 2002; Schreiner \& Spremann, 2007; Kim \& Ritter, 1999), dan untuk memprediksi keuntungan masa depan (Ou \& Penman, 1989; Fairfield, 1994; Penman, 1996).

Nilai tukar rupiah adalah nilai atau harga mata uang rupiah terhadap mata uang negara lain (Nopirin., 2009). Pergerakan nilai tukar rupiah terhadap mata 
uang asing (seperti rupiah terhadap dollar) dapat mempengaruhi investasi di dalam negeri. Menurunnya nilai rupiah dapat membuat daya tarik pasar modal berkurang karena investor lebih berhati-hati dalam melakukan investasi dalam pasar modal terutama pada perusahaan yang menggunakan bahan baku impor. Dengan melemahnya rupiah terhadap mata uang asing, investor akan memiliki alternatif lain dalam berinvestasi yaitu dengan berinvestasi pada valuta asing. Hal tersebut akan menyebabkan menurunnya permintaan akan saham sehingga harga saham akan mulai menurun.

Nilai tukar mata uang adalah perbandingan nilai atau harga antara dua mata uang yang dipertukarkan. Perbandingan nilai ini disebut dengan kurs atau exchange rate (Nopirin., 2009). Dalam penelitian sebelumnya, nilai tukar rupiah yang digunakan adalah nilai tukar rupiah terhadap dollar Amerika (US\$) karena US\$ merupakan mata uang internasional. Untuk perhitungannya, nilai tukar rupiah dapat diukur dengan nilai tengah antara kurs jual dan beli Rupiah atas Dollar AS pada setiap akhir bulan Januari 2016 sampai dengan Desember 2017. Perbandingan mata uang Indonesia yaitu rupiah (IDR) dengan mata uang Amerika Serikat yaitu dollar (USD) dengan menambahkan kedua nilai mata uang tersebut dan kemudian membaginya menjadi dua disebut dengan kurs tengah.

Kurs Tengah $=\frac{\text { Kurs Jual }+ \text { Kurs Beli }}{2}$

Produk domestik bruto atau PDB menjelaskan mengenai pendapatan serta pengeluaran total negara mengenaai output dari barang dan output dari jasa. Aktivitas ekonomi diringkas dalam suatu nilai uang. Meringkas aktivitas ekonomi pada periode tertentu tersebut merupakan tujuan dari PDB (Mankiw G, 2007). 
Laju pertumbuhan ekonomi adalah suatu proses kenaikan output perkapita jangka panjang. Penekanan pada proses karena mengandung unsur dinamis, perubahan dan perkembangan.

$\triangle P D B=\frac{P D B_{x}-P D B_{x-2}}{P D B_{x-2}} \times 100 \%$

Dimana :

$\triangle \mathrm{PDBx}=$ Laju pertumbuhan ekonomi (rate of growth)

PDB $\quad=$ Produk domestik bruto

$\mathrm{X}-1 \quad=$ Tahun sebelum

Perekonomian yang tidak mengalami peningkatan PDB nyata bisa dikatakan perekonomian berada dalam keadaan stagnasi. Perekonomian yang mengalami penurunan PDB nyata dikatakan perekonomian yang resesi, yaitu apabila penurunan tersebut tidak seberapa. Akan tetapi bisa penurunan tersebut cukup besar, gejala ini disebut depresiasi.

Penelitian ini menggunakan rasio PER sebagai proksi nilai intrinsik saham. pendekatan nilai sekarang atau present value approach dan pendekatan rasio harga terhadap earning atau PER dua pendekatan yang digunakan untuk menentukan nilai intrinsik dari saham (Tandelilin, 2010).

Menurut Vivy \& Kertahadi (2013) Price Earning Ratio menggambarkan rasio atau perbandingan antara harga saham terhadap earning perusahaan. Menurut Jones (2004) adalah satu dari banyak faktor finansial yang dianggap menarik bagi analis saham serta manajer keuangan. Literatur sebelumnya telah meneliti bagaimana rasio P/E dapat digunakan untuk memperkirakan biaya modal ekuitas (Easton, 2004), untuk menjelaskan harga saham (Liu, Nissim, \& Thomas, 
2002; Schreiner \& Spremann, 2007; Kim \& Ritter, 1999), dan untuk memprediksi keuntungan masa depan (Ou \& Penman, 1989; Fairfield, 1994; Penman, 1996).

PER memberikan informasi tentang berapa rupiah harga yang harus dibayarkan oleh investor untuk mendapatkan Rp 1,00 earning perusahaan. Secara matematis, rumus untuk menghitung PER (Tandelilin, 2010) adalah sebagai berikut:

PER $=\frac{\text { Harga Saham }}{\text { Earning per lembar saham }}$

Perusahaan non keuangan di BEI merupakan populasi darii penelitian ini. Periode yang dipilih adalah dalam jangka waktu 2016-2017 dab didapatkan 487 perusahaan sebagai populasi. Sampel dalam penelititan ini sampel diambil dengan menggunakan metode purposive sampling. Metode purposive sampling yaitu pengambilan sampel yang berdasarkan pertimbangan subyektif penelitian yang disesuaikan dengan tujuan penelitian. Teknik pengambilan sampel dengan menggunakan metode purposive sampling berdasarkan kriteria sebagai berikut perusahaan non keuangan yang terdaftar di Bursa Efek Indonesia terhitung sampai bulan desember 2017, perusahaan non keuangan harus menerbitkan laporan keuangan selama peride pnelitian., perusahaan non keuangan yang mempunyai nilai PER positif selama periode 2016-2017. Rasio ini mengindikasikan derajat kepercayaan investor pada kinerja masa depan perusahaan. Semakin tinggi PER, investor semakin percaya pada emiten, sehingga harga saham semakin mahal.

Sumber data yang digunakan dalam penelitian adalah data sekunder. Menurut Sugiyono (2017) data sekunder merupakan data yang diperoleh dengan cara menganalisis dokumen yang sudah ada, dalam penelitian ini menggunakan 
laporan tahunan perusahaan yang terdaftar di Bursa Efek Indonesia dengan mengakses situs www.idx.co.id dan ICMD.

Metode pengumpulan data yang digunakan dalam penelitian ini adalah observasi nonpartisipan. Data yang dimaksudkan adalah publikasi laporan keuangan tahunan perusahaan yang telah terdaftar pada BEI dan sesuai dengan kriteria pemilihan sampel yang terdapat di website Bursa Efek Indonesia (BEI) yaitu www.idx.co.id selama tahun 2016-2017. Data dividen dan harga pasar penutupan tahunan, penulis dapatkan dari Indonesia Capital Market Directory (ICMD) yang diterbitkan oleh Institute for Economic and Financial Research. Selanjutnya adalah studi pustaka yaitu pengumpulan data sebagai landasan teori yang didapatkan dari jurnal penelitian terdahulu, buku, dan skripsi.

Teknik analisis data yang digunakan dalam menganalisis data penelitian ini adalah analisis regresi linier berganda. Dalam analisis regresi linier berganda dilakukan uji asumsi klasik yang terdiri dari uji normalitas, multikolinearitas, uji heteroskedastisitas, dan uji autokorelasi serta pengujian hipotesis secara statistik deskriptif. Pengujian analisis regresi linier ini dibantu dengan menggunakan alat bantu yaitu, Statistical Product and Service Solutions (SPSS).

\section{HASIL DAN PEMBAHASAN}

Penelitian ini menggunakan sampel yang memenuhi kriteria pemilihan sampel yang telah ditentukan sebelumnya. Berdasarkan observasi penelitian yang dilakukan, maka perusahaan yang dapat dijadikan sampel sebanyak 283 perusahaan dengan jumlah data pengamatan selama 2 tahun sebanyak 566 . 
Tabel 1.

Kriteria Pemilihan Sampel

\begin{tabular}{clc}
\hline No & \multicolumn{1}{c}{ Keterangan } & Jumlah Perusahaan \\
\hline 1. & $\begin{array}{l}\text { Perusahaan non keuangan yang terdapat di Bursa Efek } \\
\text { Indonesia (BEI) tahun 2016-2017 }\end{array}$ & 487 \\
2. & $\begin{array}{l}\text { Perusahaan non keuangan yang secara berturut-turut tidak } \\
\text { mempublikasikan laporan keuangan tahunan periode 2016- }\end{array}$ & $(51)$ \\
& 2017 & $(153)$ \\
3. Perusahaan non keuangan yang mempunyai nilai PER negatif & \\
& selama periode 2016-2017 & 283 \\
& Perusahaan yang memenuhi kriteria sampling & $* 2$ \\
& Tahun Pengamatan \\
& Total Sampel Selama Periode Penelitian & 566 \\
\hline
\end{tabular}

Sumber: Data diolah, 2019

Variabel nilai intrinsik saham dalam penelitian ini diukur menggunakan

Price Earning Ratio menggambarkan rasio atau perbandingan antara harga saham terhadap earning perusahaan. Berdasarkan Tabel 2, nilai rata-rata PER sebesar 1156,17 bernilai positif, artinya rata-rata perusahaan memiliki nilai intrinsik saham yang baik dan mampu meningkatkan nilai intrinsik sahamnya. Nilai standar deviasi atas nilai intrinsik saham sebesar 241,29 nilai ini lebih rendah dibandingkan nilai rata-rata. Hal ini menunjukkan bahwa sebaran data nilai intrinsik saham sudah merata atau perbedaan data satu dengan data yang lainnya tidak tergolong tinggi. Nilai minimum sebesar 0,00 dimiliki oleh Sona Topas Tourism Industry Tbk. (SONA) pada tahun 2016, hal ini mengindikasikan bahwa nilai intrinsik saham perusahaan tersebut belum optimal, sementara nilai maksimum sebesar 573697,32 dimiliki oleh Bumi Teknokultura Unggul Tbk (BTEK) pada tahun 2017, dapat dikatakan bahwa perusahaan tersebut sudah mampu meningkatkan nilai intrinsik saham yang dimilikinya 
Tabel 2.

Hasil Analisis Statistik Deskriptif

\begin{tabular}{ccrrrr}
\hline Variabel & N & Minimum & Maximum & \multicolumn{1}{c}{ Mean } & \multicolumn{1}{c}{$\begin{array}{c}\text { Deviasi } \\
\text { Standar }\end{array}$} \\
\hline PER & 566 & 0,00 & 573697,32 & 1156,18 & 241,29 \\
KURS & 566 & 13473,00 & 13555,00 & 13514,00 & 41,04 \\
PDB & 566 & 5,03 & 5,07 & 5,05 & 0,02 \\
\hline
\end{tabular}

Sumber: Data diolah, 2019

Nilai tukar rupiah yang digunakan dalam penelitian ini adalah nilai tukar rupiah terhadap dollar Amerika (US\$) karena US\$ merupakan mata uang internasional. Berdasarkan Tabel 2, nilai rata-rata pada nilai tukar rupiah adalah sebesar 13,51 mendekati nilai maksimal sebesar 13,55. Standar deviasi nilai tukar rupiah sebesar 41,04 lebih rendah dibandingkan dengan nilai rata rata, artinya sebaran data terkait nilai tukar rupiah sudah merata atau perbedaan data satu dengan data yang lainnya tidak tergolong tinggi. Nilai tukar rupiah terendah sebesar 13,47 yang terjadi pada tahun 2016. Nilai tukar rupiah tertinggi adalah sebesar 13,55 yang terjadi pada tahun 2017 .

Variabel Produk Domestik Bruto dalam penelitian ini diukur melalui perkembangan PDB yang diperoleh dari Badan Pusat Statistik (BPS). Berdasarkan Tabel 1 nilai rata-rata PDB sebesar 5,05 mendekati nilai maksimum sebesar 5,07. Nilai standar deviasi PDB sebesar 0,02 lebih rendah daripada nilai rata-ratanya, artinya sebaran data PDB sudah merata atau perbedaan data satu dengan data yang lainnya tidak tergolong tinggi. Nilai PDB terendah sebesar 5,03 yang terjadi pada tahun 2016. Nilai tertinggi PDB adalah sebesar 5,07 yang terjadi pada tahun 2017. Pengujian ini dilakukan untuk menguji apakah dalam sebuah model regresi (variabel dependen atau variabel independen ataupun keduanya) memiliki distribusi normal atau tidak. Pengujian normalitas data penelitian ini 
I Komang Gede Darma Putra Sadia dan I Gde Ary Wirajaya. Pengaruh ...

menggunakan metode Kolmogorov-Smirnov. Data penelitian dikatakan berdistribusi normal apabila nilai Asymp. Sig (2-tailed) lebih besar daripada tingkat signifikansi sebesar 5\% atau 0,05. Berikut hasil uji normalitas penelitian dapat dilihat pada Tabel 3 sebagai berikut:

Tabel 3.

Hasil Uji Normalitas

\begin{tabular}{llr}
\hline & & Unstandardized \\
& & Residual \\
\hline $\mathrm{N}$ & & 566 \\
Normal Parameters & Mean & 0,000 \\
& Std. Deviation & 0,453 \\
Most Extreme Differences & Absolute & 0,127 \\
& Positive & 0,127 \\
& Negative & $-0,071$ \\
Kolmogorov-Smirnov Z & & 3,019 \\
Asymp. Sig. (2-tailed) & & 0,062 \\
\hline Sumber: Data diolah, 2019 & &
\end{tabular}

Berdasarkan tabel 3, menunjukkan nilai Asymp. Sig (2-tailed) sebesar 0,062 yang lebih besar daripada 0,05 . Hal ini berarti seluruh data pada model persamaan regresi dengan variabel dependen nilai intrinsik saham sudah berdistribusi secara normal.

Tabel 4. Hasil Uji Heteroskedastisitas

\begin{tabular}{ccc}
\hline Variabel & Sig. & Keterangan \\
\hline KURS (X1) & 0,225 & Tidak ada heteroskedastisitas \\
PDB (X2) & 0,888 & Tidak ada heteroskedastisitas \\
\hline Sumber: Data diolah 2019 & &
\end{tabular}

Berdasarkan Tabel 4 menunjukkan bahwa nilai signifikansi untuk variabel nilai tukar rupiah $\left(\mathrm{X}_{1}\right)$ sebesar 0,225 dan untuk variabel PDB $\left(\mathrm{X}_{2}\right)$ sebesar 0,888, masing-masing nilai tersebut menunjukkan nilai yang lebih besar dari 0,05 . Hal ini menunjukkan bahwa model regresi bebas dari gejala heteroskedastisitas. 
Tabel 5. Hasil Uji Multikoloniaritas

\begin{tabular}{cccc}
\hline Variabel & Tolerance & VIF & Keterangan \\
\hline KURS & 0,988 & 1,012 & Tidak ada gejala multikolinearitas \\
PDB & 0,988 & 1,012 & Tidak ada gejala multikolinearitas \\
\hline
\end{tabular}

Sumber: Data diolah, 2019

Berdasarkan Tabel 5 dapat dilihat bahwa nilai tolerance pada masingmasing variabel lebih besar dari $10 \%(0,1)$, demikian pula dengan nilai VIF masing-masing variabel yang lebih kecil dari 10. Hal ini menandakan bahwa pada persamaan regresi linier berganda dengan variabel dependen nilai intrinsik saham ini tidak terdapat kolerasi antar variabel bebas sehingga persamaan ini bebas dari gejala multikolinearitas.

Tabel 6.

Hasil Uji Autokorelasi

\begin{tabular}{ccc}
\hline $\mathrm{dW}$ hitung & $\mathrm{dW}$ tabel & Keterangan \\
& $(\mathrm{n}=566 ; \mathrm{k}=2)$ & \\
& $\mathrm{dl}=1,856 ; \mathrm{du}=1,864$ & \\
\hline 1,940 & $\mathrm{du}<\mathrm{dW}<(4-\mathrm{du})$ & Tidak terdapat autokorelasi \\
& $1,864<1,940<(2,136)$ & \\
\hline
\end{tabular}

Sumber: Data diolah, 2019

Tabel 6 menunjukkan bahwa besarnya nilai Durbin Watson sebesar 1,940.

Nilai dW menurut tabel dengan $\mathrm{n}=566$ dan $\mathrm{k}=2$ didapat nilai $\mathrm{dl}=1,856$ dan nilai du $=1,864$. Oleh karena nilai $\mathrm{du}<\mathrm{dW}<(4-\mathrm{du})$ yaitu $(1,864<1,940<$ 2,136), maka dapat disimpulkan tidak terdapat autokorelasi antar residual.

Penelitian ini menggunakan analisis regresi linear berganda, analisis regresi linear berganda digunakan untuk meneliti pengaruh variabel bebas terhadap variabel terikat serta menunjukkan arah hubungan variabel-variabel tersebut. 
Tabel 7.

Hasil Uji Analisis Regresi Linear Berganda

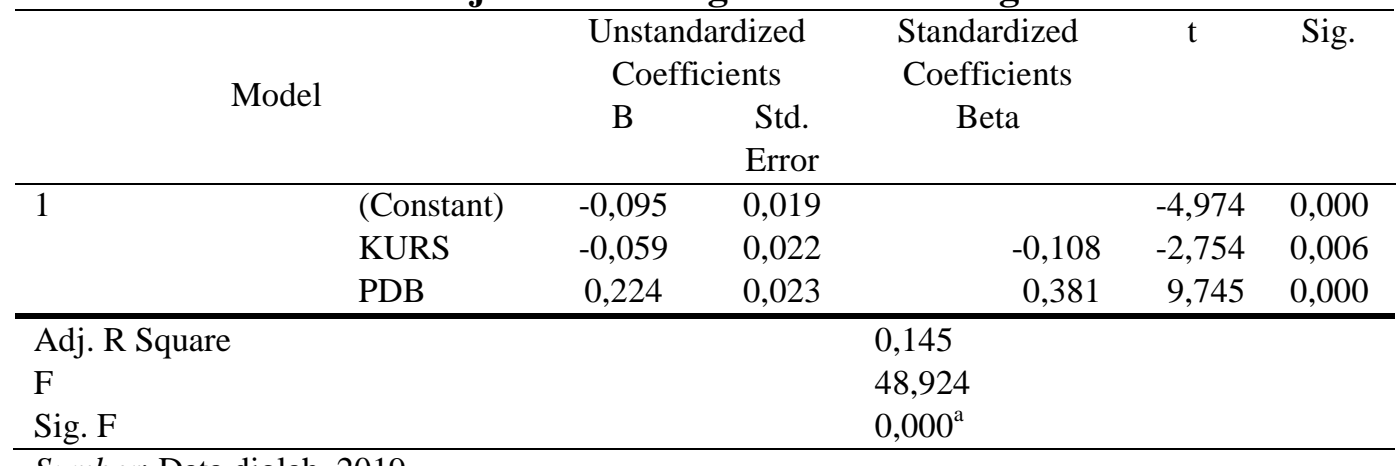

Sumber: Data diolah, 2019

Berdasarkan hasil analisis regresi linier berganda pada Tabel 7 maka persamaan regresi yang digunakan dalam penelitian ini dapat ditulis sebagai berikut:

$$
\mathrm{Y}=-0,095+-0,059 K U R S+0,224 P D B+e
$$

Keterangan:

$\begin{array}{ll}\text { Y } & : \text { Nilai Instrinsik Saham (PER) } \\ a & : \text { Konstanta } \\ \text { b1...b2 } & : \text { Koefisien regresi } \\ \text { KURS } & : \text { Nilai Tukar Rupiah terhadap US\$ } \\ \text { PDB } & : \text { Produk Domestik Bruto (PDB) } \\ e & : \text { Error term }\end{array}$

Nilai koefisien regresi nilai tukar rupiah (KURS) sebesar -0,059 memiliki nilai yang negatif menunjukkan adanya hubungan berlawanan arah, apabila nilai tukar rupiah meningkat sebesar satu rupiah, maka nilai intrinsik saham menurun sebesar 0,059 poin dengan syarat variabel bebas lainnya konstan atau sama dengan nol.

Nilai koefisien regresi produk domestik bruto (PDB) sebesar 0,224 memiliki nilai yang positif menunjukkan adanya hubungan searah, apabila PDB mengalami peningkatan sebanyak $1 \%$ akan berdampak pada peningkatan nilai 
intrinsik saham sebanyak 0,224 poin variabel bebas yang lain diasumsikan konstan.

Hasil tersebut menunjukkan pada Tabel 7 nilai Adjusted $R$ Square sebesar 0,145 yang berarti bahwa 14,5\% variasi nilai intrinsik saham yang diukur dengan PER dapat dijelaskan oleh kedua variabel independen yang terdiri dari nilai tukar rupiah dan produk domestik bruto sedangkan sisanya $85,5 \%$ dipengaruhi oleh variabel lain yang tidak dimasukkan dalam model penelitian.

Berdasarkan Tabel 7 dapat dilihat bahwa nilai $\mathrm{F}$ hitung adalah sebesar 48,924 dengan nilai signifikansi sebesar 0,000. Dasar pengambilan keputusan adalah tingkat kepercayaan sebesar 95\% sehingga tingkat kesalahan yang ditolerir (tingkat signifikansi) adalah 5\% atau 0,05. Karena nilai signifikansi $\mathrm{F}$ lebih kecil dari 0,05 maka dapat dikatakan bahwa nilai tukar rupiah dan produk domestik bruto berpegaruh secara simultan pada nilai intrinsik saham.

Tabel 7 menunjukkan nilai koefisien regresi KURS sebesar -0,059 dengan tingkat signifikansi sebesar 0,006 yang jauh lebih kecil dari 0,05. Hal ini menunjukkan nilai tukar rupiah memiliki pengaruh yang negatif pada nilai intrinsik saham. Sehingga dapat disimpulkan bahwa $\mathrm{H}_{1}$ diterima.

Tabel 7 menunjukkan koefisien regresi produk domestik bruto adalah sebesar 0,225 dengan tingkat signifikansi sebesar 0,000 yang jauh lebih kecil dari 0,05. Hal ini menunjukkan produk domestik bruto berpengaruh positif dan signifikan pada nilai intrinsik saham. Sehingga dapat disimpulkan bahwa $\mathrm{H}_{2}$ diterima. 
Hipotesis pertama menyatakan bahwa Nilai Kurs Dollar berpengaruh negatif dan signifikan terhadap nilai intrinsik saham. Berdasarkan hasil uji t, diketahui bahwa variabel Nilai Kurs Dollar mempunyai nilai koefisien regersi sebesar -0,059. Tingkat sognifikansi yang didapatkan adalah 0,006 dimana kurang dari 0,05. Maka bahwa Nilai Kurs Dollar memiliki pengaruh yang negatif pada nilai intrinsik saham.

Sesuai dengan hasil penelitian (Mirayanti, 2017). Hal ini mengindikasikan bahwa hubungan antara kurs rupiah dan nilai intrinsik saham berlawanan arah, artinya ketika kurs rupiah terhadap US\$ mengalami penguatan maka retur saham akan mengalami penurunan.

Berdasarkan Arbitrage Pricing Theory dalam penelitian ini, saat melemahnya nilai tukar rupiah maka akan menurunkan nilai pasar sehingga terdapat kesempatan untuk melakukan arbitage dengan melakukan pembelian aset dengan harga yang murah dan kemudian menjual kembali aset tersebut dengan harga yang lebih mahal yang kemudian mendapatkan laba tanpa adanya risiko. Arbitrage Pricing Theory (APT) yaitu ketika dua kesempatan investasi memiliki karakteristik-karakteristik yang serupa harus dijual dengan harga yang sama. Hukum satu harga atau the law of the one price adalah konsep yang dipakai dalam teori ini. Arbitrage akan muncul ketika melakukan pembelian aset dengan harga yang murah dan kemudian menjual kembali aset tersebut dengan harga yang lebih mahal yang kemudian mendapatkan laba tanpa adanya risiko, hal inilah yang terjadi ketika aset dengan karakteristik-karakteristik yang sama kemudian dijual dengan harga yang berbeda (Firdaus, 2016). 
ISSN: 2302-8556

E-Jurnal Akuntansi Universitas Udayana

Vol.27.3.Juni (2019): 2406-2431

Hipotesis kedua menyatakan bahwa GDP berpengaruh positif dan signifikan terhadap nilai intrinsik saham. Berdasarkan hasil uji t, diketahui bahwa variabel GDP mempunyai nilai koefisien regresi 0,225. Nilai signifikan yang didapatkan adalah 0,000 dimana kurang dari 0,05 yang berarti pertumbuhan GDP memiliki hubungan yang positif dengan nilai intrinsik saham.

Hasil penelitian ini sesuai dengan hasil penelitian Koostanto (2013). Hal ini mengindikasikan bahwa hubungan antara PDB dan nilai intrinsik saham searah. Untuk mengetahui seberapa besar pertumbungan dari produksi barang dan jasa dapat dilihat dari pertumbuhan ekonominya. Ketika terjadi pertumbuhan maka harus didukung dengan adanya investasi yang memadai sehingga dapat menunjang laju dari pertumbuhan tersebut. Dengan adanya investasi maka akan terdapat juga perkembangan pada pasar modal. PDB harus terus dijaga agar tidak terjadi gangguan pada daya beli masyarakat yaitu berupa penurunan daya beli. Jika terjadi penurunan daya beli, maka akan terjadi perubahan juga terhadap penanaman saham pada pasar modal yang kemudian berdampak pada turunnya transaksi pada pasar saham.

Berdasarkan Arbitrage Pricing Theory dalam penelitian ini, saat PDB meningkat berarti daya beli masyarakat meningkat sehingga menaikkan laba perusahaan sekaligus menaikkan harga saham perusahaan tersebut terdapat kesempatan untuk melakukan arbitage dengan melakukan pembelian aset dengan harga yang murah dan kemudian menjual kembali aset tersebut dengan harga yang lebih mahal yang kemudian mendapatkan laba tanpa adanya risiko. 
Arbitrage Pricing Theory (APT) menjelaskan ketika dua kesempatan investasi memiliki karakteristik-karakteristik yang serupa harus dijual dengan harga yang sama. Hukum satu harga atau the law of the one price adalah konsep yang dipakai dalam teori ini. Arbitrage akan muncul ketika melakukan pembelian aset dengan harga yang murah dan kemudian menjual kembali aset tersebut dengan harga yang lebih mahal yang kemudian mendapatkan laba tanpa adanya risiko, hal inilah yang terjadi ketika aset dengan karakteristik-karakteristik yang sama kemudian dijual dengan harga yang berbeda (Firdaus, 2016).

Penelitian ini diharapkan dapat memberikan kontribusi mengenai pengaruh variabel ekonomi makro pada nilai intrinsik saham. Terdapat bukti empiris yang diperoleh melalui penelitian ini yang menunjukkan bahwa nilai tukar rupiah dan produk domestik bruto berpengaruh terhadap nilai intrinsik saham pada perusahaan non keuangan. Hal ini menunjukkan bahwa tinggi rendahnya nilai tukar rupiah dan produk domestik bruto akan mempengaruhi pengambilan keputusan investor untuk melakukan investasi. Hal ini didukung dengan adanya Arbitrage Pricing Theory yang menyatakan bahwa tingkat keuntungan dapat dipengaruhi oleh berbagai faktor dalam perekonomian dan dalam industri. Hasil penelitian ini dapat menjadi pertimbangan bagi investor dalam pengambilan keputusan dalam investasi. Investor dapat menggunakan informasi fundamental eksternal perusahaan untuk menganalisis perusahaan dengan menggunakan nilai tukar rupiah dan produk domestik bruto untuk menganalisis nilai intrinsik saham pada perusahaan sehingga investor dapat memperoleh informasi fundamental yang sesuai dengan yang diharapkan. 


\section{SIMPULAN}

Hasil penelitian menunjukkan bahwa nilai tukar rupiah berpengaruh negatif pada nilai intrinsik saham. PDB meningkat berarti daya beli masyarakat meningkat. Dengan meningkatnya daya beli masyarakat maka masyarakat dapat menyerap produk-produk yang diproduksi oleh perusahaan lebih banyak dari sebelumnya. Hal ini akan meningkatkan laba yang diperoleh perusahaan sehingga dapat meningkatkan harga saham perusahaan tersebut.

Hasil penelitian menunjukkan bahwa produk domestik bruto berpengaruh positif pada nilai intrinsik saham. Jika terjadi peningkatan terhadap permintaan sebuah mata uang, sedangkan penawaran mata uang tersebut tetap atau justru menurun, maka nilai mata uang tersebut akan naik. Sedangkan jika permintaan terhadap mata uang menurun, namun terjadi peningkatan pada penawaran matauang, maka yang terjadi adalah nilai tukar uang tersebut akan akan melemah. Terjadinya perubahan terhadap nilai tukar mata uang dapat mempengaruhi sebuah perusahaan, terutama bagi perusahaan yang melakukan impor dan perusahaan yang berorientasi ekspor. Nilai mata uang yang terdepresiasi memberikan keuntungan bagi perusahaan yang berproduksi di dalam negeri dan kemudian menjual produknya di luar negeri (ekspor) karena pendapatan yang diperoleh dalam mata uang asing akan meningkat nilainya saat ditukarkan dengan mata uang rupiah, sehingga keuntungan yang didapat lebih besar. Sedangkan bagi perusahaan berproduksi dengan menggunakan bahan baku impor, yang perlu mengeluarkan biaya lebih untuk memperoleh bahan bakunya saat rupiah terdepresiasi, nilai mata uang yang terdepresiasi menyebabkan keuntungan yang 
diperoleh akan menurun. Tinggi rendahnya laba yang dapat dihasilkan oleh perusahaan akan dapat mempengaruhi nilai intrinsik saham yang mungkin diperoleh oleh investor.

Penelitian ini menjadikan perusahaan yang go public sebagai sampel penelitian sehingga diharapkan hasil penelitian ini dapat memberikan manfaat bagi perusahaan-perusahaan yang go public. Dalam melakukan peningkatan nilai intrinsik saham manajemen perusahaan perlu memerhatikan ekonomi makro sebagai pertimbangan dalam membantu dalam meningkatkan nilai instrinsik saham.

Hasil dari penilitian ini diharapkan memberikan pertimbangan bagi investor ketika akan berinvestasi ataupun mengambil keputusan yang berhubungan dengan variabel yang digunakan dalam penelitian ini. Faktor ekonomi makro perlu diperhatikan untuk dijadikan dasar pertimbangan sebelum membuat suatu keputusan. Jika ada peneliti selanjutnya yang akan mengembangkan penelitian ini, terdapat banyak variabel-variabel ekonomi makro yang dapat ditambahkan.

\section{REFERENSI}

Arif, D. (2014). Pengaruh Produk Domestik Bruto, Jumlah Uang Beredar, Inflasi Dan Bi Rate Terhadap Indeks Harga Saham Gabungan Di Indonesia Periode $2007-2013$.

Charitou, A.Gimeno-Gascon, F. Woo. C. (2004). Predicting Corporate Failure: Empirical Evidence For The UK. Europian Accounting Review, 13(3).

Dornbusch, R. at all. (2008). Macroeconomics. New York (US): McGraw-Hill Companies Inc. 
Easton, P. D. (2004). PE Ratios, PEG Ratios, and Estimating the Implied Expected Rate of Return on Equity Capital. The Accounting Review: January 2004, 79(1).

Fairfield, P. (1994). E/P, P/B and the present value of future dividends. Financial Analysts Journal, 50(4).

Fama, E. F. (1981). Stock Returns, Real Activity, Inflation and Money. American Economic Review 71.

Firdaus, M. dan I. (2016). Faktor-faktor yang Mempengaruhi Risiko Investasi Saham yang Terdaftar di Bursa Efek Indonesia Periode 2012-2014. Bandar Lampung: Universitas Lampung.

Jogiyanto. (2003). Teori Portofolio dan Analisis Investasi. (3rd ed.). yogjakarta: BPFE.

Jones, C. P. (2004). Investment: Analysis and Management. (5th ed.). New York: John Wiley \& Sons, Inc.

Kim, M., \& Ritter, J. (1999). Valuing IPOs. Journal of Financial Economics, $53(3)$.

Koostanto, H. B. (2013). Pengaruh Inflasi, Suku Bunga, Nilai Tukar, dan PDB terhadap Perubahan Tingkat Pengembalian Saham Perusahaan yang Terdaftar pada Bursa Efek Indonesia. Institut Pertanian Bogor.

Liu, J., Nissim, D., \& Thomas, J. (2002). Equity valuation using multiples. Journal of Accounting Research, 40(1).

Mankiw G. (2007). Makroekonomi. Jakarta: Erlangga.

Mirayanti, N. M. (2017). Pengaruh Variabel Ekonomi Makro Pada Return Saham LQ45 Di Bursa Efek Indonesia. E-Jurnal Akuntansi, Vol. 21(1).

Nopirin. (2009). Ekonomi Moneter. (1st ed.). Jakarta: BPFE.

Ou, J. A., \& Penman, S. (1989). Accounting Measurement, Price-Earnings Ratio, and the Information Content of Security Prices. Journal of Accounting Research., 27.

Penman, S. (1996). The articulation of price-earnings ratios and market-to-book ratios and the evaluation of growth. Journal of Accounting Research, 34(2).

Rachmawati, Rini. (2012). Analisis Variabel Mikro dan Makro Terhadap Kesulitan Keuangan Pada Perusahaan Tekstil dan Produk Tekstil. 
Schreiner, A., \& Spremann, K. (2007). Multiples and their valuation accuracy in European equity markets (Working paper).

Sugiyono. (2017). Metode Penelitian Kualitatif Kuantitatif dan R\&D. Bandung: Alfabeta.

Sulistyastuti. (2002). Saham \& Obligasi, Ringkasan Teori dan Soal Jawab. Yogjakarta: Universitas Atma Jaya Yogyakarta.

Tandelilin, E. (2010). Portofolio da Investasi: Teori dan Aplikasi. (1st ed.). Yogyakarta.

Thobarry, A. A. (2009). Analisi Pengaruh Nilai Tukar, Suku Bunga, Laju Inflasi, dan Pertumbuhan GDP terhadap Indek Harga Saham Sektor Properti. Semarang: Universitas Diponegoro Semaran.

Vivy Diah Nourmasari, Kertahadi, D. (2013). Analisis Fundamental Internal untuk Menilai Kewajaran Harga Saham dengan Pendekatan Price Earning Ratio (Studi pada Perusahaan Semen yang Terdaftar di BEI Periode 20092011). Jurnal Jurnal Administrasi Dan Bisnis, 5(2).

Wulandari, D. (2010). Analisis Pengaruh Kebebasan Ekonomi dan VariabelVariabel Ekonomi Moneter terhadap Harga Saham di Lima Negara ASEAN. Disertasi, Program Doktor Ilmu Ekonomi Kekhususan Manajemen Universitas Brawijaya.

Www.bi.go.id. (2017). Bank Indonesia. 